\title{
JOB COUNSELING A TOOL FOR SOCIAL INCLUSION: EMPIRICAL RESEARCH IN POLAND
}

\author{
Mariola Szewczyk-Jarocka, doctor \\ Faculty of Economics and Information Technology, The State University of Applied Sciences in Plock, Poland
}

\begin{abstract}
The main purpose of the considerations presented in the article is to determine the benefits that are conducive to the social inclusion of the unemployed, most often socially excluded people using job counselling. Questionnaire surveys, according to the interview questionnaire, were carried out on a population of 350 respondents in 2018. The research shows that there is a statistically significant relationship between the use of job counseling and the length of the registration period in the labour office. Among people who were registered for at least 3 months, there were more people who used job counseling. Choosing or changing a profession (approximately $41 \%$ of respondents' answers) and completing professional qualifications (slightly more than $43 \%$ of responses) are the most often indicated benefits. There was a statistically significant relationship between gender and the indication of career planning. Men declared this answer more often.
\end{abstract}

Key words: job counseling, social inclusion, benefits from job counseling.

JEL code: E24, E26, J46.

\section{Introduction}

Social inclusion enables excluded people to enter the registered labour market.

The most important motives for undertaking the research subject include the following premises:

- willingness to verify the widespread belief that job counseling is an instrument of social inclusion,

- lack of comprehensive research on the phenomenon of social inclusion.

Taking into account the above premises, the main purpose of the considerations presented in the article is to determine whether unemployed people use job counseling.

The research task was to assess what benefits the job counseling provides.

The gathering of information regarding social inclusion was primarily based on the empirical study designed and conducted by the author.

The following specific objectives have been adopted for such a general research framework:

1. determining if the unemployed have used job counselling;

2. understanding the benefits that job counseling provides.

The conclusions from the empirical study, supported by the information obtained from secondary sources used in the article, made it possible to verify the following hypotheses:

$\mathrm{H} 1$ : The use of job counseling depends on the length of the registration period at the Municipal Labour Office in Plock;

$\mathrm{H} 2$ : Planning a career is the main benefit from the use of the job counseling indicated by the surveyed men.

\section{Research results and discussion}

Based on the data collected during the research, the author attempted to get the answer to the research questions.

- Did socially excluded people use the job counseling?

- What benefits does the job counseling provide?

The literature on the subject and author's research carried out as a part of the research grant the "Cooperation with universities" project was used to implement the presented research task. Statistical tests and descriptive methods were used. The author presented the results in tabular form and charts. 


\section{Organization of the research}

\section{Analysed data}

Questionnaire surveys by interview questionnaire were conducted in 2018 on a population of 350 respondents (195 people surveyed using paper questionnaires and 155 people surveyed using a questionnaire posted on the Internet).

Plan of statistical analyses

The analyses covered the distribution of responses to survey questions in the entire sample and verification of the statistical significance of the relationship between the responses given and such variables as: gender, age, education and length of registration in the Municipal Labour Office. As a statistical significance threshold - a value of 0.05 was conventionally assumed. Statistical significance was examined based on the values of the likelihood quotient, which is used to analyse the relationships between categorical variables, i.e. those that divide the subjects into groups in a situation where some of the categories distinguished are not very numerous.

Respondents

The research was conducted among 350 respondents, 226 women (64.6\%) and 124 men (35.4 \%). Two hundred and seventy-four residents of Plock (78.3\%) and 73 residents of the outskirts of Plock (20.9\%).

\section{The concept of social inclusion}

According to J. Grotowska - Leder, K. Faliszek, the process of getting out of social exclusion is called social inclusion $(\ldots)$, that is, creating people who are threatened with social exclusion with opportunities and adequate resources needed for full participation in economic, cultural and social life and achieving a standard of living as normal in a given society (Grotowska - Leder, Faliszek, 2005: (63)). In order to give this process logic, it should be considered in three dimensions: political, economic and civic (Woodward, Kohli, 2003: (1-4)).

Inclusion activities carried out in three above mentioned dimensions mean the implementation in practice of multi-sectoral social policy (Grewinski, 2009).

Following B. Szatur - Jaworska, according to the contemporary concept of social policy, social inclusion is the process of "including" marginalized people in the so-called the stream of life through full participation in social life (Szatur - Jaworska, 2005).

According to B. Broda-Wysocki, the definitions of social inclusion put an important emphasis on external impact in relation to excluded individuals or groups. They call for "creating opportunities" or "community actions". The assumption here is that social inclusion is a deliberate, deliberately undertaken action of organized entities. On the basis of recognizing various reasons for social exclusion, various social inclusion strategies are also formulated. There are different strategies: reproductive, palliative, preventive and emancipation (Broda - Wysocki, 2012: (178)).

\section{The role of a job}

A job is one of the concepts of economic theory. Through work, man shapes himself and acquires skills (Lange, 1978: (16)). The job is approached as coercive, but also as well as through creative expression (Nowak, 2011: (235-236)).

In macroeconomic terms, we treat work as a resource of production function factors alongside capital (Fihel, Piętka, 2007: (34)) and technology (Baily, Friedmann, 1991: (688-689)). 
The consciousness of human labour was recently created, because earlier humanity treated it as an element of survival (Orczyk, 2004: (15-16)). Thanks to economic benefits, work has improved the quality of life (Sobczak, 2016: (60 and further)).

\section{Job counseling as a tool for social inclusion (empirical research)}

According to the survey, 177 persons surveyed (50.6\%) benefited from the job counselling at the Municipal Labour Office in Plock.

There was No statistically significant relationship between the use of the job counseling and the gender of the respondents, $\lambda(1)=0.01, p>0.05$ education, $\lambda(2)=0.10, p>0.05$, or age, $\lambda(1)=0.31$, $p>0.05$. However, a statistically significant relationship was obtained between the use of the job counseling and the length of the registration period in the labour office, $\lambda(1)=4.16, p<0.05$.

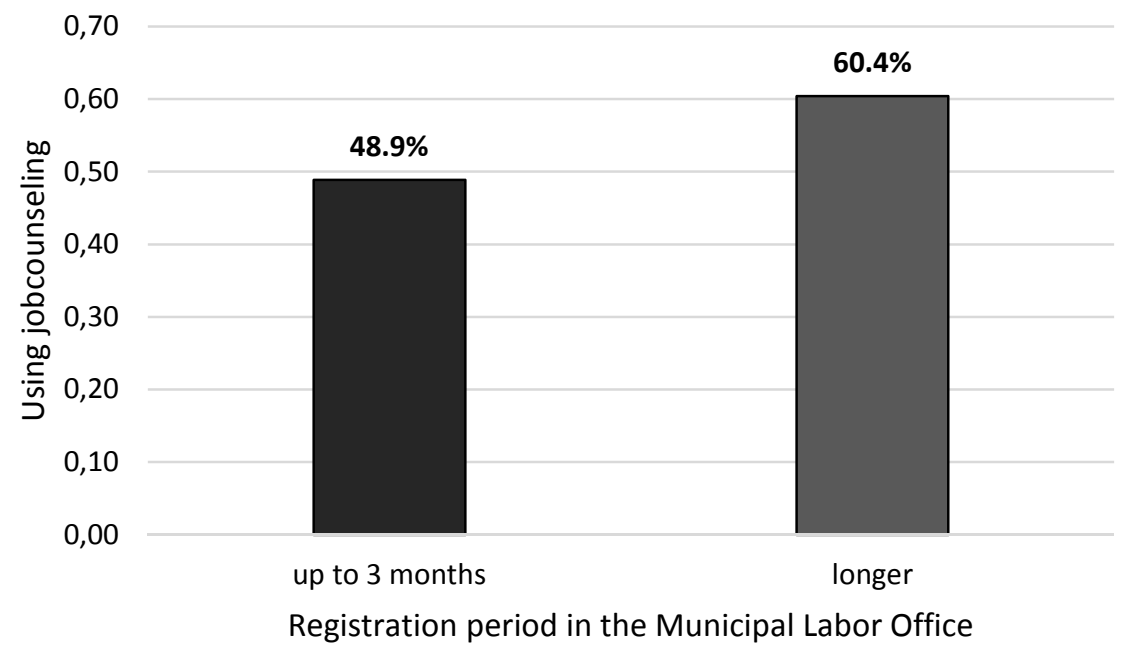

Source: Author's study based on surveys

Fig. 1. Using career counseling depending on the length of the registration period at the Municipal Labour Office in Plock

Among persons who were registered for at least 3 months, there were more respondents who used the job counseling (Figure 1).

Table 1 presents the frequency distribution for the indicated benefits of the job counseling.

Table 1

\section{Indicated benefits of job counseling}

\begin{tabular}{|l|c|c|}
\hline \multicolumn{1}{|c|}{ Advantages } & n & \% \\
\hline choosing or changing a profession & $\mathbf{1 4 3}$ & $\mathbf{4 0 . 9}$ \\
\hline planning a career & 87 & 24.9 \\
\hline completing professional qualifications & $\mathbf{1 5 2}$ & $\mathbf{4 3 . 4}$ \\
\hline defining your professional competences & 133 & 38.0 \\
\hline planning professional development & 79 & 22.6 \\
\hline
\end{tabular}

$n$ - number of respondents; \% - the percentage of the group

Source: Author's study based on surveys

Most often the benefit indicated by the survey was the choice or change of the profession (about $41 \%$ of respondents' answers) and the completion of professional qualifications (slightly over $43 \%$ of responses). 
Table 2 presents the values of the likelihood ratio, by means of which the dependencies between the number of respondents, education, age and period of registration in the Municipal Labour Office in Plock were analysed, and the indicated benefits and the values of the strength of the Cramer's $\mathrm{V}$ measure.

Table 2

Analysis of the relationship between the gender of the respondents, age, education, registration period in the Municipal Labour Office in Plock, and the benefits indicated

\begin{tabular}{|c|c|c|c|c|c|}
\hline & Advantages & $\lambda$ & $\boldsymbol{d f}$ & $\boldsymbol{p}$ & $\boldsymbol{V}$ \\
\hline \multirow{5}{*}{ Gender } & choosing or changing a profession & 0.66 & 1 & 0.415 & 0.04 \\
\hline & planning a career & 4.98 & 1 & 0.026 & 0.12 \\
\hline & completing professional qualifications & 1.46 & 1 & 0.227 & 0.07 \\
\hline & defining your professional competences & 0.04 & 1 & 0.847 & 0.01 \\
\hline & planning professional development & 0.14 & 1 & 0.705 & 0.02 \\
\hline \multirow{5}{*}{ Education } & choosing or changing a profession & 8.56 & 2 & 0.014 & 0.16 \\
\hline & planning a career & 5.85 & 2 & 0.054 & 0.13 \\
\hline & completing professional qualifications & 1.12 & 2 & 0.572 & 0.06 \\
\hline & defining your professional competences & 0.24 & 2 & 0.885 & 0.03 \\
\hline & planning professional development & 0.21 & 2 & 0.902 & 0.02 \\
\hline \multirow{5}{*}{ Age } & choosing or changing a profession & 0.01 & 1 & 0.949 & 0.00 \\
\hline & planning a career & 0.24 & 1 & 0.623 & 0.03 \\
\hline & completing professional qualifications & 0.31 & 1 & 0.575 & 0.03 \\
\hline & defining your professional competences & 2.55 & 1 & 0.110 & 0.09 \\
\hline & planning professional development & 0.06 & 1 & 0.814 & 0.01 \\
\hline \multirow{5}{*}{$\begin{array}{l}\text { Registration } \\
\text { period }\end{array}$} & choosing or changing a profession & 0.05 & 1 & 0.829 & 0.01 \\
\hline & planning a career & 0.01 & 1 & 0.928 & 0.00 \\
\hline & completing professional qualifications & 0.42 & 1 & 0.519 & 0.04 \\
\hline & defining your professional competences & 0.05 & 1 & 0.826 & 0.01 \\
\hline & planning professional development & 2.57 & 1 & 0.109 & 0.09 \\
\hline
\end{tabular}

$\lambda$ - value of the likelihood ratio; $d f$ - the number of degrees of freedom; $p$ - statistical significance;

$V$ - the value of Cramer's $V$ measure

Source: Author's study based on surveys

A statistically significant relationship between gender and career planning was obtained. This benefit was more often indicated by men (Figure 2 ). 


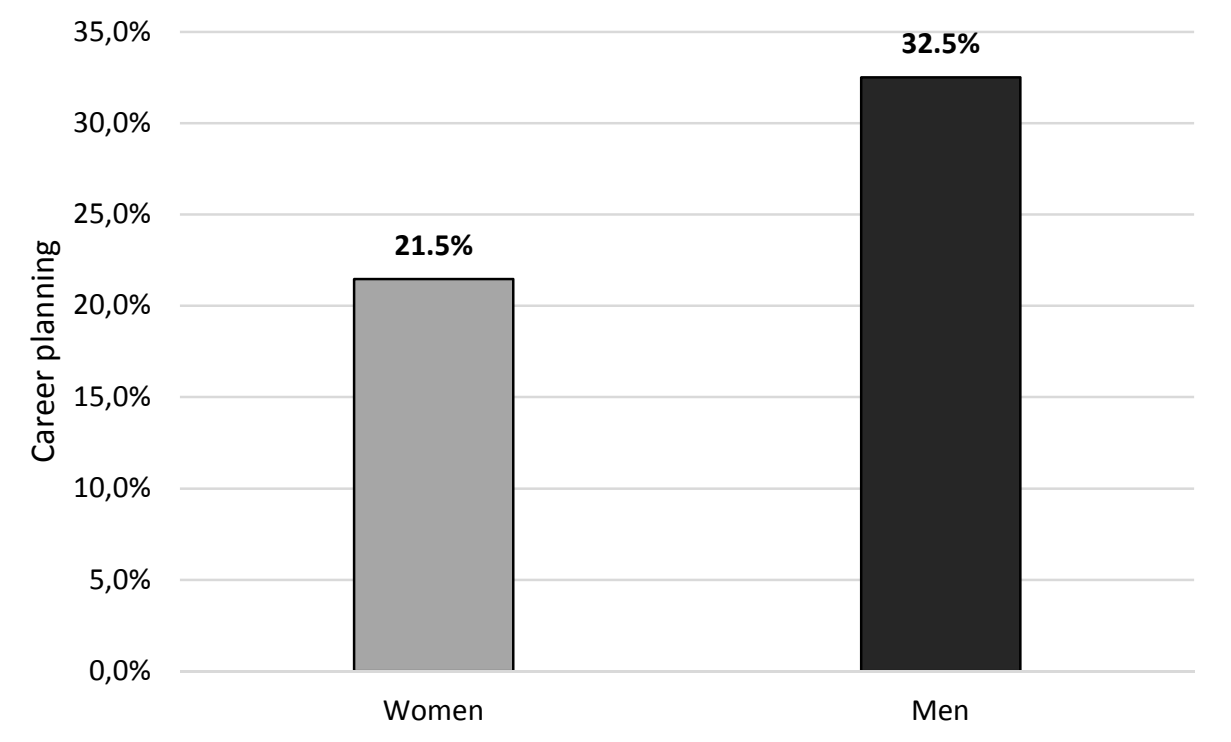

Source: Author's study based on surveys

Fig. 2. Indicated career planning in a group of women and in a group of men

\section{Conclusions, proposals, recommendations}

The job counseling is an important element in helping the unemployed find employment. The unemployed do use the job counseling.

The research shows that between the use of the job counseling and the length of the registration period in the labour office there is a statistically significant relationship $(\lambda(1)=4.16, p<0.05)$. Among people who were registered for at least 3 months there were more people who used the job counseling.

The most frequently mentioned were the benefits of using the job counseling, i.e. the choice or change of the profession (about $41 \%$ of respondents' answers) and the completion of professional qualifications (slightly more than $43 \%$ of responses).

In addition, a statistically significant relationship was found between gender and the job counseling $(\lambda(1)=4.98, p<0.05)$. Men declared this answer more often.

\section{Bibliography}

1. Baily, M.N., Friedmann, p. (1991). Macroeconomics, Financial Markets, and the International Sector. Richard D. Irwin, Inc., Boston.

2. Broda-Wysocki, p. (2012). Wykluczenie i inkluzja spoleczna. Paradygmaty i proby definicji (Exclusion and social inclusion. Paradigms and attempts at definitions], Warszawa (Warsaw), IPiSS (Institute of Labour and Social Studies).

3. Fihel, A., Pietka, E. (2007). Funkcjonowanie polskich migrantow na brytyjskim rynku pracy (Functioning of Polish migrants on the British labor market). CMR Working Papers. Warszawa (Warsaw). UW (Warsaw University)

4. Gerwinski, M. (2009). Wielosektorowa polityka spoleczna. O przeobrazeniach Panstwa opiekunczego (Multisectoral social policy. On the transformations of your welfare state), Warszawa (Warsaw), WWSP TWP (The Higher School of Pedagogy of the Society of Public Knowledge in Warsaw).

5. Grotowska - Leder, J., Faliszek, K. (Ed.) (2005). Ekskluzja i inkluzja spoleczna. Diagnoza - uwarunkowania - kierunku dzialan (Exclusion and social inclusion. Diagnosis - conditions - direction of activities), Torun , Wydawnictwo Edukacyjne (Educational Publisher) AKAPIT-DTP .

6. Lange, O. (1978). Ekonomia polityczna (Political economics). Tom I i II (Volume I and II). Warszawa (Warsaw). PWN (Polish Scientific Publishers).

7. Nowaka, K. (2011). Status pojecia pracy w teorii krytycznej i teorii ekonomii (The status of the concept of work in critical theory and economic theory), WNIF UAM w Poznaniu (University of Adam Mickiewicz in Poznan).

8. Orczyk, J. (2004). Przemiany pracy na obecnym etapie rozwoju gospodarczego (Changes in labor at the current stage of economic development) (in:) Golinowska S., Boni M (ed.). W trosce o prace . Raport o rozwoju społecznym (For the sake of work. Report on social development) Polska (Poland) 2004. Warszawa (Warsaw). Program Narodow Zjednoczonych ds. Rozwoju (United Nations Development Program). 
9. Sobczak, M. J. (2016). Wykluczenie spoleczna i inkluzja spoleczna z wykorzystaniem podmiotow ekonomii spolecznej w Polsce na przykładzie wojewodztwa lodzkiego (Social exclusion and social inclusion with the use of social economy entities in Poland on the example of the Lodz province), Lodz , Wydawnictwo Uniwersytetu Lodzkiego (Lodz University Publisher).

10.Szatur - Jaworska, B. (2005). Uwagi o ekskluzji i inkluzji na przykładzie polityki spolecznej wobec ludzi starszych (Comments on exclusion and inclusion on the example of social policy towards older people) (in:) Grotowska - Leder J., Faliszek K. (Ed.) (2005). Ekskluzja i inkluzja spoleczna. Diagnoza - uwarunkowania kierunku dzialan (Exclusion and social inclusion. Diagnosis - conditions - direction of activities), Torun , Wydawnictwo Edukacyjne (Educational Publisher) AKAPIT-DTP.

11. Woodward, A., Kohli, M. (2003). Inclusion and Exclusion in European Societies, London-New York, Routledge. 